\title{
Variability of zonation patterns in temperate microtidal Uruguayan beaches with different morphodynamic types
}

\author{
Luis Giménez*, Beatriz Yannicelli \\ Facultad de Ciencias, Sección Oceanografía, Tristán Narvaja 1674, 11200 Montevideo, Uruguay
}

\begin{abstract}
Early studies on sandy beach zonation patterns have shown rather rigid schemes. Recent work has suggested that zonation changes with morphodynamic type and, in dissipative beaches, it also changes through time. This last finding leads to the conclusion that at least $1 \mathrm{yr}$ of study is necessary to understand zonation patterns in dissipative sandy beaches. Here we report a 1 yr study (from March 1994 to March 1995) of 4 microtidal beaches with different morphodynamic types situated on the Atlantic coast of Uruguay. We show that zonation patterns (number of zones or belts) can change through time regardless of beach type. However, the morphodynamic characteristics of the beach seem to affect how frequently the zonation pattern can change by fusion or subdivision of zones, and which zones are involved in those processes. In beaches with flat slopes (toward the dissipative extremity), the lower zones were frequently fused and divided. The same occurred with the medium and upper zones in the beaches with steeper slopes (towards the reflective extremity). Our results suggest that spatial variability of the macrofauna is related to variability in the position of the swash zone, which in turn depends on beach slope and width. Variability of specles distribution would also depend on morphological adaptations of organisms to move in such environments. We suggest 2 mechanisms of species movement to explain the variability in species distribution observed in this study: Swash Mediated Active Movement (SMAM) and Autonomous Active Movement (AAM). The first mechanism involves both an active and a passive component. AAM is independent of swash movements and affects species distribution on the upper levels of the beach.
\end{abstract}

KEY WORDS: Sandy beaches S Seasonal variability - Zonation pattern - Morphodynamic types Uruguay

\section{INTRODUCTION}

Several schemes have been devised to describe community structure in sandy beaches (see McLachlan \& Jaramillo 1995 for review). Earlier models proposed rather static zonation schemes which have been considered to be universal. They described zonation patterns as zones or belts, parallel to the water line, characterized by 3 biological (Dahl 1952) or 4 physical (Salvat 1964) zones. Dahl's (1952) zones were characterized by ocypodid crabs or talitrid amphipods (subterrestrial fringe), cirolanid isopods (midlittoral zone) and hippid crabs or haustorid amphipods (sublittoral

\footnotetext{
-Present address: Biologische Anstalt Helgoland, Meeresstation Helgoland, Postfach 180, D-27483 Helgoland, Germany
}

fringe) respectively. Salvat's (1964) zones were defined as follows: (1) drying zone: only wetted by spray during high tides; (2) retention zone: reached during all tides and hence retaining some water; (3) resurgence: a bright zone subjected to considerable water movement; and (4) the water saturated zone: always covered by water. A general model has been proposed by Brown (Brown \& McLachlan 1990), where 2 belts are predicted to occur: an upper one of air breathing organisms and a lower one of water breathing organisms.

Using a multivariate approach, Raffaelli et al. (1991) found that the zonation pattern of a British beach followed neither Dahl's nor Salvat's schemes and they suggested that Brown's model was the most appropriate to explain their observations. Defeo et al. (1992) and Jaramillo et al. (1993) showed that there is not a 
constant number of zones in temperate sandy beaches, and that zonation patterns depend on beach morphodynamics. They also pointed out that Brown's model explained the zonation patterns observed. More recently, Brazeiro \& Defeo (1996), working on a dissipative microtidal sandy beach, found that zonation patterns changed seasonally or even at shorter time intervals. Furthermore, they noted that the peak in the distribution of the representative species in each zone could also occur in adjacent zones. They proposed that variations in species distribution were due to temporal changes in the position of the swash zone.

The findings of Brazeiro \& Defeo (1996) have not been tested on other beach types (i.e. reflective beaches or beaches with intermediate characteristics) and it is not known how widespread such variation patterns might be. To determine if variation of the zonation pattern is a prevailing feature of sandy beaches, different beach types ranging from dissipative to reflective conditions were studied for $1 \mathrm{yr}$. The main questions to answer were: (1) Does sandy beach zonation pattern and species distribution change with time regardless of beach type? (2) What factors are responsible for temporal changes in the zonation pattern of sandy beaches?

In this study we investigate the relationship between spatial variability of the macrofauna and variability in the position of the swash zone and we propose 2 mechanisms of species movement by which changes in species spatial distribution may take place.

\section{MATERIALS AND METHODS}

Study area. Cabo Polonio $\left(34^{\circ} 23^{\prime} \mathrm{S}, 53^{\circ} 46^{\prime} \mathrm{W}\right)$ is a rocky peninsula on the east coast of Uruguay (Fig. 1). On each side of the cape there is a beach arc extending for several kilometers, limited by sand dunes of variable height which move in a NE direction. These beach arcs display dissipative characteristics that become more reflective as distance from the rocky cape increases (Piñeiro \& Panario 1993). The coast experiences a semidiurnal tide (range of less than $0.5 \mathrm{~m}$ ), but water level is mostly influenced by wind direction and speed. Winds blow mainly from the south-west during winter and the north-east during summer (Piñeiro \& Panario 1993).

Three sampling sites $2 \mathrm{~km}$ apart were chosen on the eastern beach arc: (1) on a reflective beach (Barco); (2) on an intermediate beach (Duna); and (3) on a dissipative beach (Calavera). A 4 th sampling site was located on the southern arc on Sur beach (Fig 1).

Sampling. Sampling was carried out monthly from March 1994 to March 1995, except in May and November, when no samples were taken for logistic reasons,

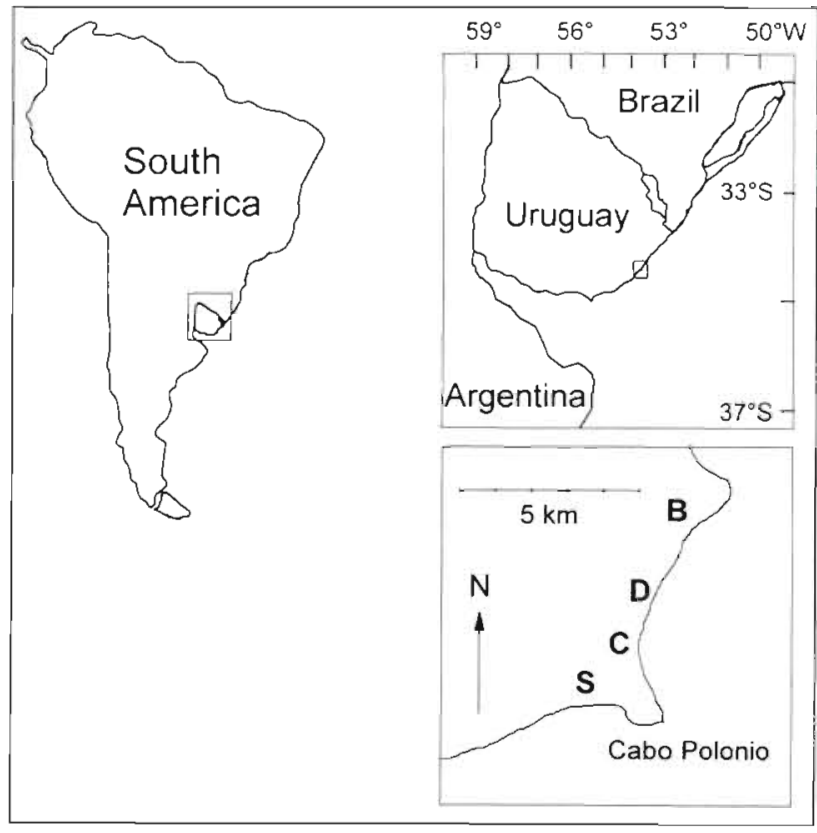

Fig. 1 Geographic location of Cabo Polonio and the studied beaches ( $\mathrm{S}$ : Sur beach; C: Calavera beach; D: Duna beach, B: Barco beach)

and April and July, when not all 4 beaches could be sampled. Four transect lines perpendicular to the shoreline were extended at each sampling site from the dune line to the lower limit of the swash zone. At each transect line, 1 sample unit was taken at beach levels (stations) every $4 \mathrm{~m}$, starting with Stn 1 at the dune line. Sampling units consisted of 2 core samples $18 \mathrm{~cm}$ in diameter and $20 \mathrm{~cm}$ deep. Cusps were detectable in all sampling sites, so transect lines were laid successively on crests and troughs. Distance between the crests was about $40 \mathrm{~m}$ in the eastern beach and $60 \mathrm{~m}$ in the southern one. Sediment was sieved through a $1 \mathrm{~mm}$ sieve and all macrofauna retained in the sieve was fixed in 5\% formalin and taken to the laboratory. Species were identified and counted in the laboratory.

Beach slope and water content of the sediment were measured seasonally (spring, winter, fall and summer 1995) at least at one of the transect lines of all sampling sites. Beach slopes were determined using a clinometer; sediment samples were wrapped in aluminum foil, weighed soon after collection, dried at $80^{\circ} \mathrm{C}$ for $24 \mathrm{~h}$, and weighed again to determine water content. Another set of sediment samples, collected in February 1994 were oven dried $\left(80^{\circ} \mathrm{C}\right.$ for $\left.24 \mathrm{~h}\right)$ and passed through a series of sieves ranging from -2 phi $(\phi)$ to $6 \phi$ (in $1 \phi$ intervals). Mean grain size was determined following the Folk \& Ward (1957) methodology.

Water content of different beach levels and seasons were compared using linear regressions of the log-trans- 
formed water content $(\ln W)$ on distance from the dune line $\left(D_{\mathrm{d}}\right)$ for each beach and period $\left(\ln W=\mathrm{a}+\mathrm{b} \cdot D_{\mathrm{d}}\right)$. Tests for the significance of the regression lines, homogeneity of slopes tests and equality of intercepts were carried out following Zar (1974).

Morphodynamic types of all sites were determined following Short \& Wright (1983) and exposure to wave action was estimated from physical and biological parameters, following McLachlan's (1980) rating system. Wave height was estimated from photographic records of waves with known references.

Data analyses. To determine changes in community structure, a multivariate classification technique (cluster analysis) was applied to macrofauna abundance data. Macrofauna abundance $(N)$ of all transects of a given site and month were pooled for each beach level $\left(N \cdot 0.16 \mathrm{~m}^{-2}\right)$. Cluster analysis was carried out using Bray-Curtis index (Field et al. 1982) on the log-transformed data $(\log N+1)$. Dendrograms were obtained from the dissimilarity matrix by Unweighted Pair Group Matching Analysis (UPGMA; Legendre 1979). Groups were defined at the 0.5 dissimilarity level. Stations that joined at higher levels (single stations at 0.5 ) were not considered a group. However, as groups (and therefore zones) were formed, information on their extrinsic characteristics helped us decide on the best zones defined by the dendrograms (Clifford \& Stephenson 1975). In a few cases, this resulted in stations being excluded from the groups, as for Calavera beach Stns 3 and 6 in October 1994 and for Duna Stn 2 in March 1994. These stations were joined by the UPGMA because of the scarcity or the rarity of their fauna, but did not constitute a zone as defined by Dahl (1952). Another multivariate method (multidimensional scaling) was also tried and the results broadly agreed with those of the cluster analysis. However, using cluster analysis, groups could be defined in a more objective manner and, therefore, we will show and refer only to the results of this method. For simplicity, only representative dendrograms and graphs of spatial distribution are presented in Figs. 3 to 6 . These representative graphs correspond to months that are underlined throughout the text.

To quantify variability in spatial distribution through time, the modal position of each species was used to

Table 1. Main physical characteristics and morphodynamic types of 4 Unuguayan sandy beaches studied from March 1994 to March 1995

\begin{tabular}{|c|c|c|c|c|}
\hline & Calavera & Duna & Barco & Sur \\
\hline Width $(\mathrm{m})$ & 60 & 48 & 44 & 96 \\
\hline Exposure rating & 11 & 13 & 15 & 12 \\
\hline Exposure & Exposed & Exposed & Exposed & Exposed \\
\hline Morphodynamic type & Dissipative & Intermediate & Reflective & Intermediate \\
\hline
\end{tabular}

calculate 2 indices: mean squared deviation $(C M)$ from the annual average position of the mode of each species distribution, divided by beach width; and mean amplitude $(A M)$ by dividing the annual average mode by beach width.

$$
C M=\frac{\sum\left(X-x_{j}\right)^{2}}{n \cdot L} \quad A M=\frac{\sum\left|X-x_{i}\right|}{n \cdot L}
$$

where $X$ is the mean modal position on the beach through the study period, expressed as beach level (every $4 \mathrm{~m})_{i} x_{i}$ is the modal position during month $i$; $n$ is the number of monthly samples at the site; and $L$ is the level of the lower limit of the swash zone.

We explored possible relationships between variability in species distribution and variability of the swash zone position through the use of correlation analyses. Swash zone position was recorded as the maximum and minimum beach level reached by the waves. Variability of the swash zone position was studied employing a modification of the $C M$ and $A M$ indices described above, using $X$ as the annual mean of the lower limit of swash zone; $x_{j}$ as the position of that limit in month $i_{i}$ and $n$ as the number of months that the position of the swash zone was recorded.

\section{RESULTS}

\section{Physical characteristics of the beaches}

\section{Calavera}

Calavera sediments could be categorized as fine sands (average $\phi=2.1$ ). However, mean grain size increased towards the swash zone reaching values in the medium to coarse sand range, mostly because of the accumulation of shells hash retained in the $-2 \phi$ sieve. The beach profile was gentle (mean slope $=2.61^{\circ}$ ) and remained rather constant throughout the study period. The average area sampled on each occasion was $2.1 \mathrm{~m}^{2}$ [ranging from $1.4 \mathrm{~m}^{2}$ in April 1994 (hereafter all months in 1994 given without year) to $2.6 \mathrm{~m}^{2}$ in January 1995 due to changes in beach width]. On the longshore axis the beach was almost homogeneous except for very flat cusps. There were no macrofaunal burrows present, the reduced layer was situated below $0.5 \mathrm{~m}$ deep, and wave height was usually above $1 \mathrm{~m}$. Therefore, this site was defined as an exposed, dissipative beach (see Table 1).

Sediment water content increased from the dune line to the swash zone $[\mathrm{p}(b=0) \ll 0.01$ for all months tested] and changed with time at all beach levels (Fig. 2). The slope of the water 

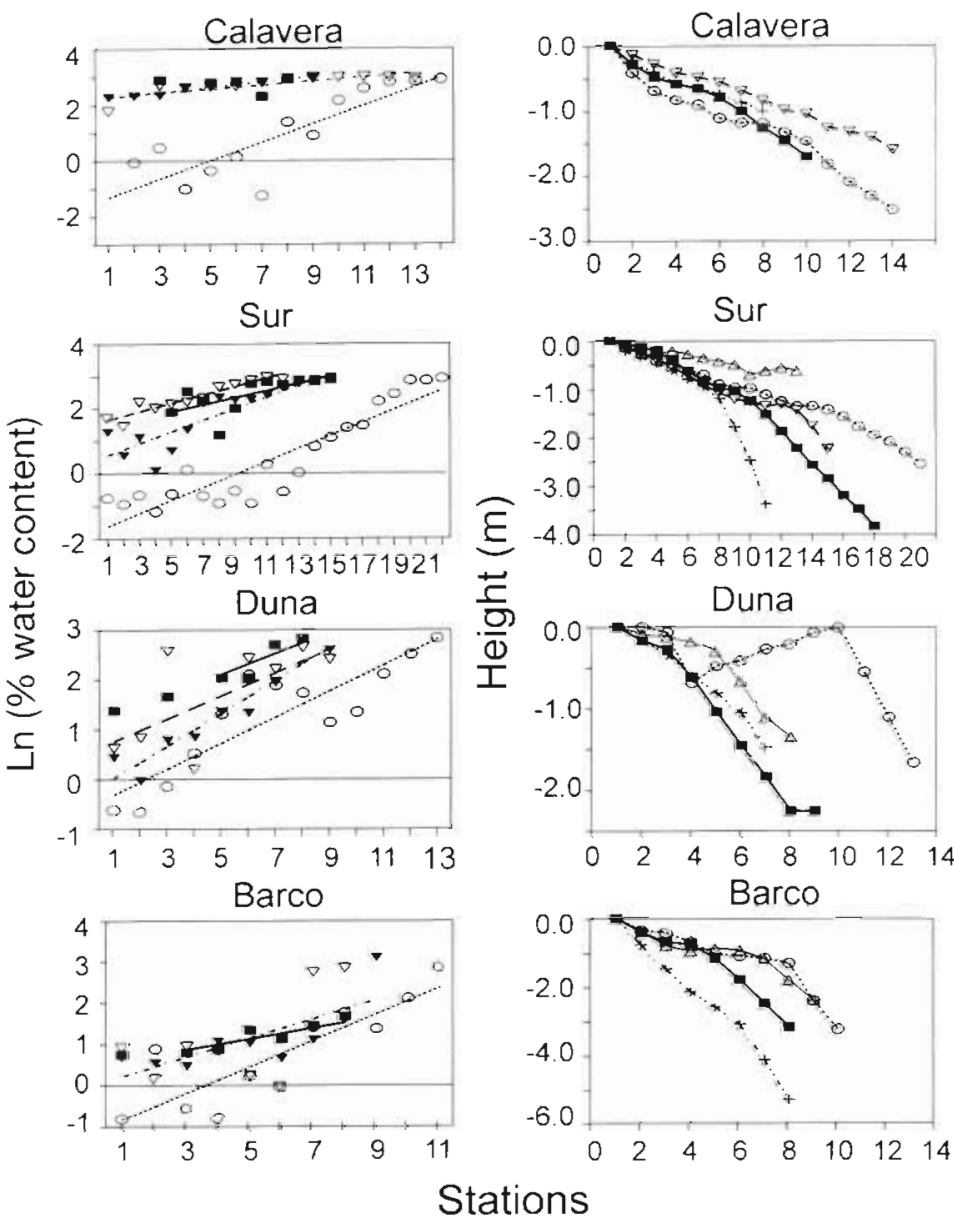

Fig. 2. Temporal and spatial changes in sediment water content (ln of $\%$ content) and beach slope (as relative height from the dune line) on 4 Uruguayan beaches. Stn 1 is at the dune line and the last station on the right corresponds to the lower limit of the swash zone at the time of the sampling. Regression lines were all significant $(p \ll 0.05)$. ( . $\odot)$ January 1995; ( $\rightarrow-$-) March 1994; (......) June 1994; (- $\nabla-)$ July 1994; $(\rightarrow$ ) August 1994; (. - ...) September 1994

content regression during summer was significantly higher than during the other months (test for homogeneity of slopes, $p<0.01$ ) indicating that sediment water content of the higher beach levels was lower in summer

\section{Sur}

This beach showed sediments with an average $\phi$ value of 1.8 (medium sand) that did not change along the beach profile. Sur beach also showed a gentle slope (mean value $2.65^{\circ}$ ), although noticeable increases in beach slope were observed during March $\left(8^{\circ}\right)$ and June $\left(6.5^{\circ}\right)$. The average area sampled on each occasion was $3.12 \mathrm{~m}^{2}$ (ranging from $2 \mathrm{~m}^{2}$ in June to $4 \mathrm{~m}^{2}$ in January 1995, due, as in Calavera, to changes in beach width). On the longshore axis, the beach showed more conspicuous cusps than those of Calavera beach, with crests about $60 \mathrm{~m}$ apart. The beach lacked macrofaunal burrows, the reduced layer was deeper than $0.5 \mathrm{~m}$ and wave heights of about $1 \mathrm{~m}$ were common. This site was classified as an exposed, intermediate beach with longshore bar-through (Table 1), which puts it closer to the dissipative type in the Short \& Wright (1983) classification system.

Sediment water content increased from 0 to $10 \%$ at the dune line to $20 \%$ at the swash zone $[\mathrm{p}(b=0) \ll 0.01$ for all months tested] and changed with time at all beach levels (Fig. 2). It was lower in summer than in winter but the difference was homogeneous throughout the whole beach (test for homogeneity of slopes: $p>0.25$; $p$ (intercepts) $\ll$ $0.01\}$.

\section{Duna}

Average grain size increased from the dune to the swash zone, ranging from medium sands $(\phi=1.6)$ at the upper levels of the beach, to coarse sand $(\phi=0.7)$ in the swash zone. Beach profile changed seasonally: in March and June the beach was narrow and steep $\left(\right.$ width $=24$ to $32 \mathrm{~m}_{\text {i }}$ mean slope $=4.1^{\circ}$ ) while in January 1995 it became wider (52 m) and sediment accumulated towards the swash zone as a sandy shoal or a low tide terrace (Fig. 2). This pattern was also observed in September and October. The total area sampled each month ranged between $1.1 \mathrm{~m}^{2}$ in June to $2.2 \mathrm{~m}^{2}$ in January 1995, the annual mean being $1.9 \mathrm{~m}^{2}$.

Longshore variation consisted of cusps about $40 \mathrm{~m}$ apart. There were no macrofaunal burrows; the reduced layer was deeper than $0.5 \mathrm{~m}$ and waves commonly reached $1 \mathrm{~m}$ high or more. This site was defined as an exposed, intermediate beach, belonging probably to the transverse bar rip or low tide terrace types (Short \& Wright 1983) closer to the reflective end (Table 1).

There were important seasonal and spatial changes in sediment water content (Fig. 2). The general trend was an increase in water content from the dune line to the swash zone $[\mathrm{p}(b=0)<0.01$ for all months tested]. At high beach levels, water content was low (4 to $6 \%$ ) except in July (12\%); at medium beach levels water content ranged from 6 to $16 \%$; and at low beach levels values ranged from 10 to $20 \%$. However, in July and January 1995, sediment water content peaked at inter- 
mediate beach levels. Seasonal variation in sediment water content was homogeneous throughout the whole beach (test for homogeneity of slopes: $\mathrm{p}>0.46$ ).

\section{Barco}

Average grain size increased from the dune to the swash zone, ranging from medium sands $(\phi=1.2)$ at the upper levels of the beach to coarse sand $(\phi=0.2)$ in the swash zone. Beach profile and beach width were more stable than at the intermediate beaches (Duna and Sur). Barco showed low to moderate slopes at high and medium beach levels (up to $7.5^{\circ}$ ) and a very pronounced slope in the swash zone (up to $10^{\circ}$ ). The mean area sampled at this site was $1.8 \mathrm{~m}^{2}$ (ranging from $1.6 \mathrm{~m}^{2}$ in July to $2.1 \mathrm{~m}^{2}$ in January 1995). There were cusps present with distance between consecutive crests of about $40 \mathrm{~m}$. There were no macrofaunal burrows, the reduced layer was deeper than $0.5 \mathrm{~m}$ and wave height usually exceeded $1.5 \mathrm{~m}$. This site was defined as an exposed, reflective beach (Table 1).

The sediment water content was consistently low $(2 \%)$ at the upper and medium beach levels and increased toward the swash zone, where it reached values of 16 to $20 \%$ (Fig. 2). Slopes of the regressions were significant $[p(b=0)<0.02]$ for all months but July.

\section{Zonation pattern}

\section{Calavera}

The number of zones defined by cluster analyses changed throughout the year (Fig. 3). In March, June, August, December, February 1995 and March 1995, cluster analysis determined 2 zones: a lower one characterized in most cases by Emerita brasiliensis and Donax hanleyanus and an upper one characterized by cirolanid isopod species. However, the upper zone did not always comprise the same species, with different assemblages occurring: (1) the upper zone was defined by Excirolana armata and Excirolana braziliensis (in March); (2) the upper zone was defined by E. armata alone (in June, August and December); and (3) the upper zone was defined by E. braziliensis alone, while E. armata was found in the lower zone (in February 1995 and March 1995). Two zones were also found in July (an upper and a middle one), since the remaining stations (all belonging to the swash zone) failed to form a group. In April, species dis-
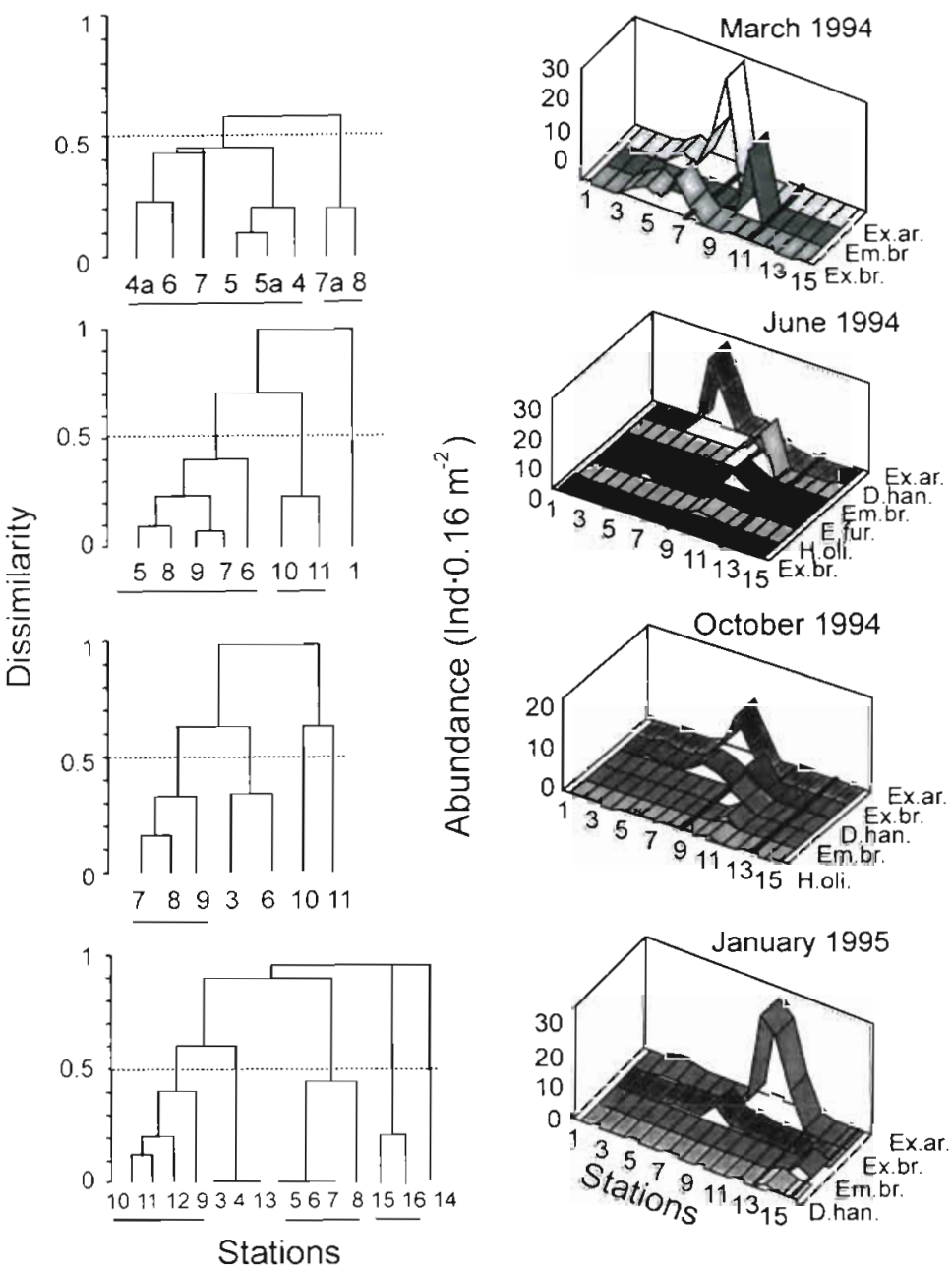

Fig. 3. Dendrograms and spatial distribution of most abundant species at Calavera in representative months of the period March 1994 to March 1995. Horizontal thick lines below the dendrograms join stations defining the zones or belts. Thick lines which cross species distribution represent the upper and lower limits of the swash zone. Species abbreviations: Ex.ar., Excirolana armata; Ex.br., Excirolana braziliensis; Em.br., Emerita brasiliensis; D.han., Donax hanleyanus; H.oli., Hemipodus olivieri; Efur., Euzonus furciferus

tributions were highly overlapped and 2 groups could be defined, but at dissimilarity levels higher than 0.5 .

In September and October only 1 cluster was formed at the selected level, defining an upper zone characterized by Excirolana armata and Excirolana braziliensis (Fig. 3). The remaining stations (mainly from the swash zone) were joined at higher dissimilarity levels. In the lower beach Donax hanleyanus, Hemipodus olivieri and Emerita brasiliensis were found in very low abundance.

In January 1995 cluster analysis distinguished 3 zones: the upper one was characterized by Excirolana braziliensis, the middle zone by Excirolana armata and the lower one by Emerita brasiliensis (Fig. 3) 



Stations

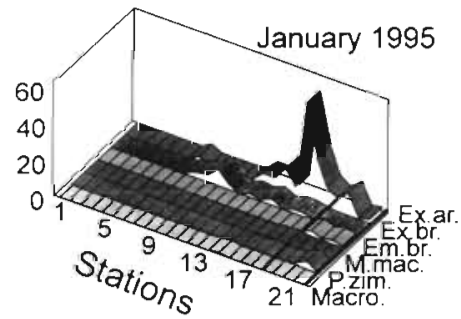

Fig. 4. Dendrograms and spatial distribution of most abundant species at Sur in representative months of the period March 1994 to March 1995. Species abbreviations as in Fig. 3, except for: M.mac., Mesodesma mactroides; P.zim., Poxocephalopsis zimmeri, Macro., Macrochiridotea sp.

zone was characterized by Excirolana braziliensis. The middle zone was characterized by $E$ armata (in July and August), E. armata and E. braziliensis (in January 1995), or E. armata, E. braziliensis and Euzonus furciferus (in March 1995). The lower zone was characterized by Emerita brasiliensis, Donax hanleyanus, Phoxocephalopsis zimmeri and Mesoderma mactroides, although not all of them were present all the time. E. armata was also present in this zone albeit at very low numbers (Fig. 4)

In December and June, only 2 zones were defined: the upper one was characterized by Excirolana braziliensis, the lower one by Excirolana armata, Emerita brasiliensis, Hemipodus olivieri, Donax hanleyanus and Macrochiridotea sp. (Fig. 4)

\section{Duna}

In March, October, December and March 1995, 2 groups were defined that corresponded to an upper zone characterized by Excirolana braziliensis and Orchestoidea brasiliensis and a lower zone characterized by Emerita brasiliensis, Donax hanleyanus and Hemipodus olivieri (Fig. 5).

In June, August and September, only 1 group was formed at the chosen dissimilarity level, corresponding to those stations dominated by Excirolana braziliensis (June and August) or Orchestoidea brasiliensis (September). The stations in the swash zone, characterized by Emerita brasiliensis,

Sur

The number of zones defined in this beach fluctuated between 2 and 4 , but most commonly there were 3 zones (Fig. 4). In April and September, there were 4 zones (Fig 4): the upper zone was characterized by the isopods Excirolana armata and Excirolana braziliensis in April and only by E. braziliensis in September; the next zone was characterized by E. armata and Emerita brasiliensis in April but only E. armata in September; the third zone, corresponding to the swash zone, was defined by Donax hanleyanus (April) along with E. armata and Emerita brasiliensis, which were present in September; finally, the lowest zone was characterized by the amphipod Phoxocephalopsis zimmeri in April and Emerita brasiliensis in September.

In July, August, October, January 1995 and March 1995, 3 zones were identified. In all cases the upper Donax hanleyanus and Hemipodus olivieri in very low numbers, did not form a cluster (Fig. 5).

In February 1995, 3 zones were defined: the upper zone was characterized by Excirolana braziliensis in low abundance, the middle one by E. braziliensis and Orchestoidea brasiliensis, and the lowest zone by Emerita brasiliensis, Donax hanleyanus and Hemipodus olivieri.

\section{Barco}

In March, June, August, September, October and February 1995, 2 zones were defined. The upper zone was characterized by Orchestoidea brasiliensis or Excirolana braziliensis or both, while the lower zone was characterized by Emerita braziliensis, Donax hanleyanus and Hemipodus olivieri (Fig, 6) 
In July, December, January 1995 and March 1995, 3 zones were determined (Fig. 6): in July and December, Excirolana braziliensis characterized the upper zone, Orchestoidea brasiliensis the middle zone and Donax hanleyanus and Hemipodus olivieri the lowest zone. In March 1995, O. brasiliensis characterized a zone in the upper part of the beach and Excirolana braziliensis appeared mostly next to the upper limit of the swash zone and also near the dunes.

\section{Temporal changes in swash zone position and species distribution}

Upper and lower swash zone limits followed a seasonal pattern at all the studied sites: swash zone limits were closer to the dune line from late summer to winter (February to August) and moved towards the lower levels of the beach during spring and early summer (Fig. 7). This pattern was more evident at the beaches on the dissipative extremity (Calavera and Sur), where swash zone limit variability was larger, than at the beaches on the reflective end (Duna and Barco), where swash zone limits did not vary as much (Fig. 8)

Modal position of the various species was also more variable at Calavera and Sur beaches as compared to the Duna and Barco. At Calavera the distribution mode of Emerita brasiliensis, Excirolana armata, Excirolana braziliensis and Donax hanleyanus were all very close, overlapped or swapped positions in March, April, June, October, December and February 1995 (Fig. 7). At Sur, overlapping and swapping of the distribution mode was mostly restricted to swash zone species Emerita brasiliensis and $D$. hanleyanus. At Barco and Duna, species distributions were fairly stable and well defined, except for Orchestoidea brasiliensis whose distribution mode ranged from the upper limit of the swash zone almost to the dune line (Fig. 7)

Variability in species spatial distribution, as measured by the $C M$ and $A M$ indices, increased with swash zone variability $(C M$ : $r=0.80, p \ll 0.01$; $A M$ : $r=0.51, p=0.041$ for pooled data). Maxima $C M$ values were recorded at Sur and minima at Barco (Fig. 8). Species AM maxima were recorded at Calavera, which had intermediate levels of swash zone variability, while minima were recorded at Barco (Fig. 8).

There were also interspecific differences in variability of spatial distribution. In general, Donax hanleyanus presented lower variability than Excirolana
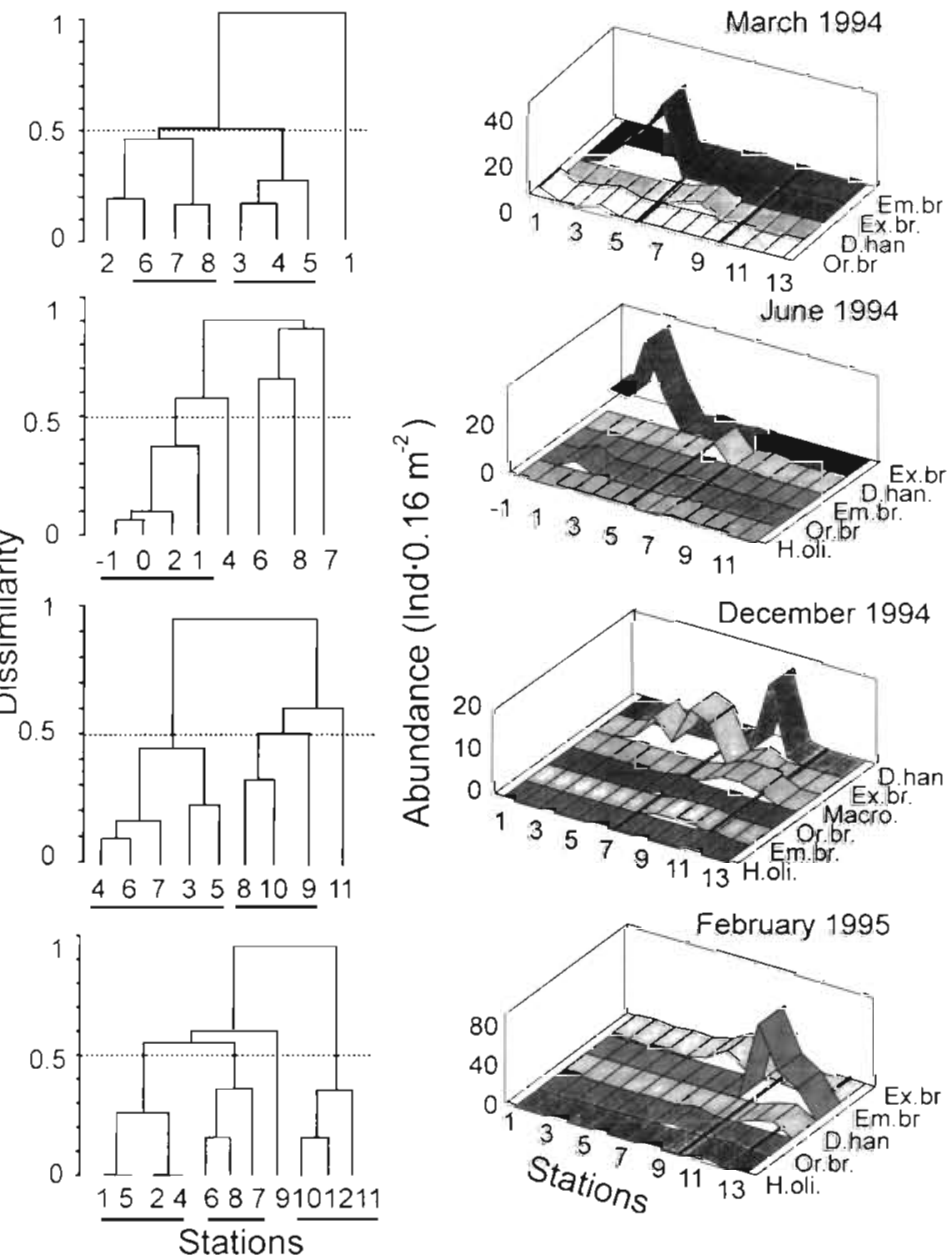

Fig. 5. Dendrograms and spatıal distrabution of most abundant species at Duna in representative months of the period March 1994 to March 1995. Species abbreviations as in Figs. 3 \& 4, except for: Or.br., Orchestoidea brasiliensis. Stns 0 and -1 in June 1995 correspond to samples taken 4 and $8 \mathrm{~m}$ above the dune line, respectively, due to the presence of E. braziliensis

braziliensis and Emerita brasiliensis. At Calavera and Sur, the least variable species was Excirolana armata (for $C M$ ); however at Sur (for $A M$ ) it has the highest value. In the intermediate and reflective beaches (Duna and Barco) Orchestoidea brasiliensis had the highest spatial variability among all species.

\section{DISCUSSION}

\section{Zonation}

In general, 3 zones could be distinguished in beaches of Cabo Polonio: an upper one defined by Excirolana braziliensis; a middle one defined by Excirolana armata or Orchestoidea brasiliensis; and a lower one defined by Donax hanleyanus and Emerita 

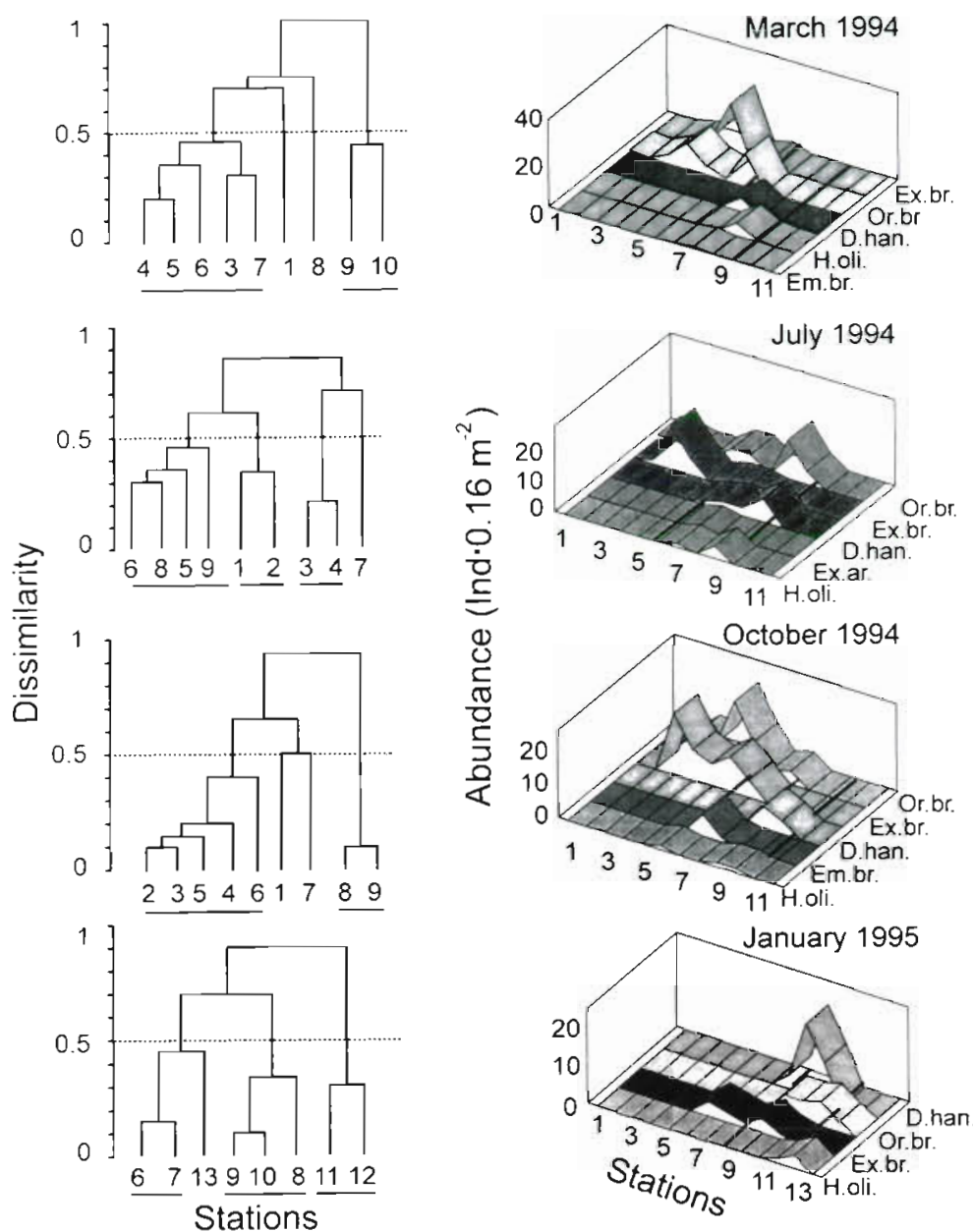

Fig. 6. Dendrograms and spatial distribution of most abundant species at Barco in representative months of the period March 1994 to March 1995. Species abbreviations as in Figs. 3 to 5 brasiliensis. However, 2 main characteristics of zonation pattern changed with time: (1) the number of zones and (2) species occurrence in a given zone. The number of zones varied from 1 to 4 among all beach types and tended to be at a maximum in the widest beach (Sur). These findings are in agreement with those of Defeo et al. (1992), who could not establish a unique zonation pattern for 5 Uruguayan sandy beaches, and with the results of Brazeiro \& Defeo (1996), who showed that the zonation pattern of a dissipative beach could change through time. It may then be more appropriate to define the zonation pattern of Uruguayan sandy beaches as shifting between different 'states', which are characterized by the number of zones and have variable frequency of occurrence.

We could not observe a clear increase in the number of zones from reflective to dissipative beaches, as found by Jaramillo et al. (1993), when the frequency of occurrence of the various states was considered. At Barco (the reflective beach) the frequency of the 2-zone state was $6 / 10$ while the 3 -zone state was $4 / 10$; at Calavera (the dissipative beach) the frequency of the 2-zone state was $6 / 11$ while the 3 -zone state was $1 / 11$. Sur, a wide flat beach that could not be classified as fully dissipative, reached a 2 -zone state in only 2 mo out of 10 , the 3 -zone state 6 mo out of 10 , and the 4 -zone state 2 mo out of 10 , suggesting that beach width is also an important parameter in determining the variability of the zonation pattern.

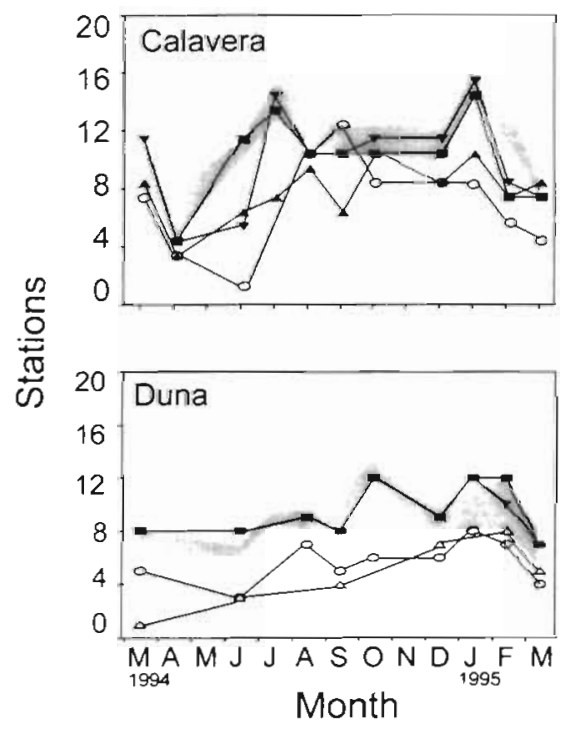

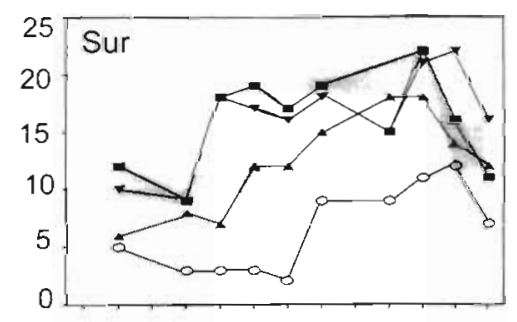

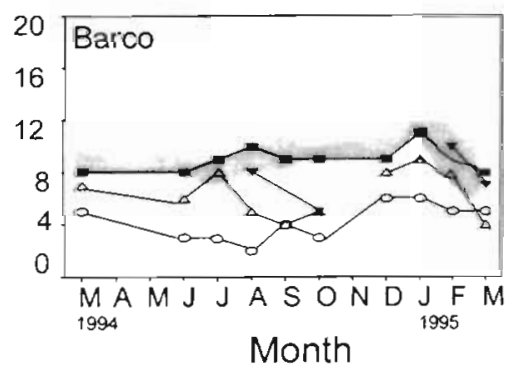

Fig. 7. Temporal changes in the position of the distribution mode for the most abundant species found during this study. Stations range from 1 , at the dune line, to the lower limit of the swash zone (shaded area). (0) Excirolana braziliensis, (^) Excirolana armatai $(\nabla)$ Emerita brasiliensis, (-) Donax hanleyanus, ( $\Delta$ ) Orchestoidea brasiliensis 
Fig. 8. Swash zone (a) mean square deviation (CM) and (b) mean amplitude $(A M)$ in relation to mean beach slope, and species (c) CM and (d) $A M$ in relation to swash zone spatial variability (as $C M$ and $A M$ respectively). C: Calavera; D: Duna; B: Barco; S: Sur. Species abbreviations as in Figs. 3 to 5
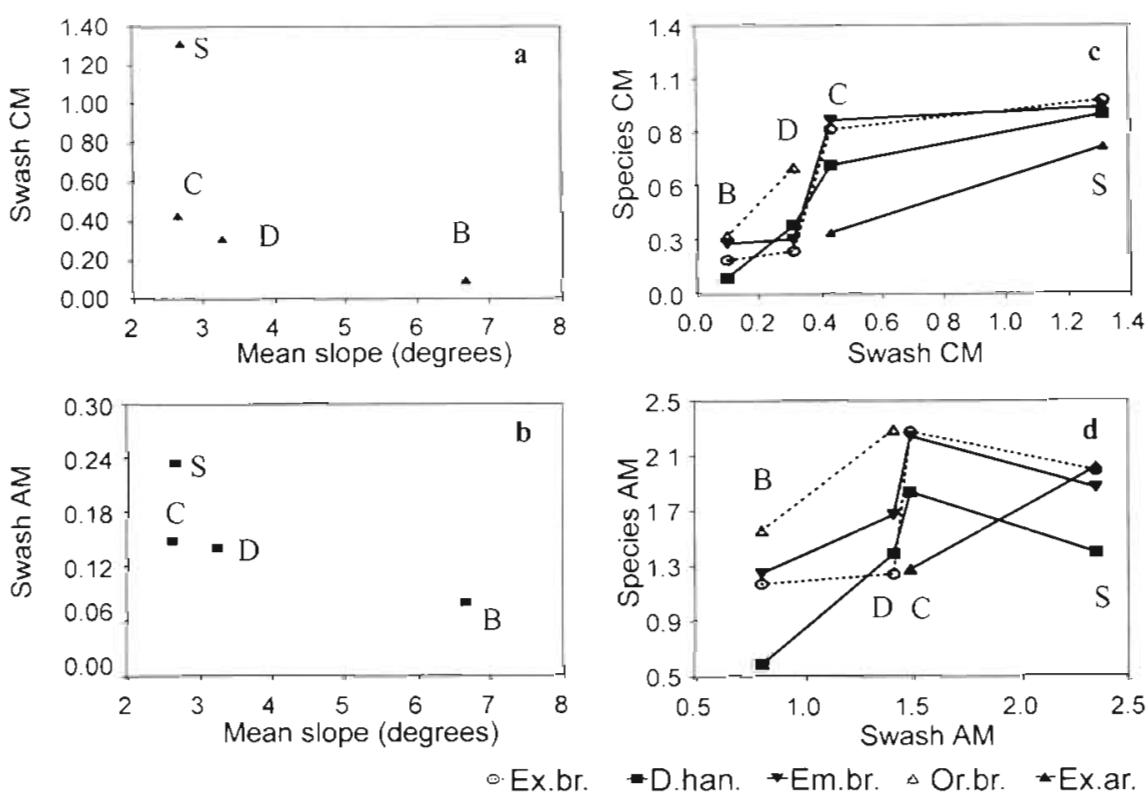

Total area sampled in some cases was less than the 3 to $4 \mathrm{~m}^{2}$ recommended by Jaramillo et al. (1995), so the occurrence of a species at a given site could have been missed, adding to the variability of the zonation pattern. However, area sampled depended on beach width, and for all the beaches sampled, the months with the most samples did not necessarily coincide with the greatest number of zones defined.

Species distribution at times overlapped or swapped adjacent zones, resulting in the different 'states' observed. At a flat beach such as Sur, Excirolana braziliensis defined a very stable zone in the upper portion of the beach. Excirolana armata defined an intermediate zone in the upper limit of the swash zone and above, while Donax hanleyanus and Emerita brasiliensis defined the lower zone (swash zone and below), or E. armata could overlap the lower zone and the 3 species characterized a single zone. At times, a 4 th zone emerged in the lower limit of the swash, characterized by the amphipod Phoxocephalopsis zimmeri. At Calavera, the other flat beach studied, Excirolana braziliensis occasionally overlapped the middle zone defined by E. armata, to form a cirolanid zone at the middle-to-upper beach level.

At steep beaches, Emerita brasiliensis and Donax hanleyanus defined the most stable zone (along the swash zone). Excirolana braziliensis and Orchestoidea brasiliensis defined the upper zone of the beach or overlapped to the middle zone or, alternatively, did not clearly define a zone but rather were distributed in isolated patches. In most cases, $O$. brasiliensis defined a zone below the $E$. braziliensis zone. This is in contrast to Dahl's (1952) general scheme and the observations of Escofet et al. (1979), who always found the talitrid amphipods on the upper zone.

\section{Relationship between physical parameters and zonation pattern}

Swash climate as a factor affecting community dynamics has been proposed by McArdle \& McLachlan $(1991,1992)$ and Brazeiro \& Defeo (1996). Our findings provide strong support for this hypothesis, since swash zone variability is most likely correlated to swash climate features such as upswash distance. Variability in species spatial distribution increased from reflective to dissipative beaches, suggesting that the latter would harbor the most variable communities regarding spatial distribution.

The correlation between swash zone variability and beach slope suggested that slope was the main factor controlling variability in zonation patterns: at dissipative beaches (Calavera and Sur), swash zone variability was high due to their gentle slopes, while at the reflective ones (Barco and Duna), it was low due to the steep slopes. At microtidal dissipative beaches small tidal changes lead to large changes in swash zone position and overlapping species distributions, while at reflective beaches, swash zone position is more stable, avoiding the overlap between 'swash zone' (e.g. Emerita braziliensis) and 'upper swash' species (e.g. Excirolana brasiliensis).

At the beaches studied, seasonal changes in wind direction (Piñeiro \& Panario 1993) could be responsible for the observed variations in swash zone position throughout the year. During winter (when the swash 
zone is found at a higher beach level), dominant winds pile water shoreward, while during summer months, dominant winds move water seaward. Also, the orientation of the beaches studied could have an effect on the swash zone position and variability. Sur beach, which faces south, is more exposed to the southwest winds and has a higher swash zone variability than Calavera beach, which faces east.

Temporal changes in species distribution may be a consequence of differences in morphological adaptations of the organisms to move and bury in the sandy beach environment. The amphipod Orchestoidea brasiliensis had higher variability in distribution pattern than any other species. This could be due to the fact that $O$. brasiliensis is able to jump up to $10 \mathrm{~cm}$ or more (L.G. pers. obs.) allowing it to rapidly cover a larger area while seeking favorable conditions or avoiding adverse ones. Species whose locomotion capability depend on swash movement (Emerita brasiliensis or Donax hanleyanus) are confined to a narrow and rather stable distribution in reflective beaches.

In general, changes in species distribution as a consequence of changes of swash zone position could occur by different mechanisms. Brazeiro \& Defeo (1996) postulated 2 processes, active movement and passive transport, and suggested that these processes may be related to animal size: large animals may exhibit active movement while small ones are subjected to passive transport. The variability in species distribution observed in this study could be explained by 2 mechanisms of active movement, Swash-Mediated Active Movement (SMAM) and Autonomous Active Movement (AAM). The first mechanism would be the one exhibited by organisms living directly in the swash zone and involves both an active and a passive component. The active component is given by one or more of the following processes: (1) recognition of wave action, as shown by Jones \& Naylor (1970) and Jones \& Hobbins (1985) for the isopod Eurydice pulchra; (2) perception of sediment disturbance, as in the sand crab Emerita analoga (Cubit 1969); (3) a circatidal or a more flexible swimming rhythm (McLachlan et al. 1979, De Ruyck et al. 1991); and (4) active digging in order to avoid stranding, as in the case of bivalve molluscs (Narchi 1979). These active processes involved in the SMAM favor zonation maintenance (see Alheit \& Naylor 1976 for isopods). The passive component consists of the energetic contribution of the swash to the total transport, which could be minimal in the case of the most active swimmers, or comprise all of the horizontal movement. Passive transport by swash would be more important in small sized organisms, such as Excirolana armata and Excirolana braziliensis, as concluded by Brazeiro \& Defeo (1996). However, more information is needed about active swimming of Uruguayan isopods since $E$. braziliensis does not display swimming rhythms on Chilean beaches (Jaramillo \& Fuentealba 1993) but it reportedly does so on Panamanian beaches (Weinberg \& Starczak 1988). Examples of species inhabiting Uruguayan beaches that display SMAM would be the tidal migrators Emerita brasiliensis, Donax hanleyanus and Mesodesma mactroides.

The second mechanism (AAM) is independent of swash movements and involves the use of morphological adaptations for active motion on the sandy beach environment. AAM is the mechanism exhibited by ocypodid crabs or sand hopper amphipods (such as Orchestoidea brasiliensis in Uruguayan beaches), which occurs off the swash zone.

In summary, we consider beach slope and beach width to be the main factors explaining species distribution and variability in zonation patterns in microtidal sandy beaches. Gentle slopes, such as those characteristic of dissipative beaches, result in larger swash displacements that in turn allow larger variability on species spatial distribution. Zonation pattern is more variable due to overlapping of species over several zones. Steep slopes, such as those found in reflective beaches, reduce swash zone displacements, and hence the movement of SMAM species, giving more stability to the lower zones

Acknowledgements. This work was partially financed by funds from the Instituto de Biología, Facultad de Ciencias, Universidad de la República, Montevideo. We thank Dr Raúl Palacios for his constructive comments and advice during the initial writing of this paper We also thank Dr Omar Defeo, Dr Anton McLachlan, and 2 anonymous reviewers for their critical reading and useful comments on an early version of the manuscript. The fieldwork would not have been possible without the help of E. Peluffo, C. Olivera, J. Sellanes, G. Torres, P. Elola and other students who helped us during this study.

\section{LITERATURE CITED}

Alheit J, Naylor E (1.976) Behavioural basis of intertidal zonation in Eurydice pulchra Leach. J Exp Mar Biol Ecol 23: $135-144$

Brazeiro A, Defeo O (1996) Macronfauna zonation in microtidal sandy beaches: is it possible to identify patterns in such variable environments? Estuar Coast Shelf Sci 42: 523-536

Brown A McLachlan A (1990) Ecology of sandy shores. Elsevier, Amsterdam

Clifford HT, Stephenson W (1975) An introduction to numerical classification. Academic Press, New York

Cubit J (1969) Behavioural and physical factors causing migration and aggregation of the sand crab Emerita analoga (Stimson). Ecology 50:118-123

Dahl E (1952) Some aspects of the ecology and zonation of the fauna on sandy beaches. Oikos 4:1-27

Defeo O, Jaramillo E, Lyonnet A (1992) Community structure and intertidal zonation of the macroinfauna on the Atlantic coast of Uruguay. J Coastal Res 8:830-839 
De Ruyck M, McLachlan A, Donn T (1991) The activity of 3 intertidal sand beach isopods (Flabellifera: Cirolanidae) J Exp Mar Biol Ecol 146:163-180

Escofet A, Gianuca N, Maytía S, Scarabino V (1979) Playas arenosas del Atlántico Sudoccidental ente los $29^{\circ}$ y $43^{\circ}$ Lat. Sur: Consideraciones generales y esquema biocenológico. In: Memorias del seminario sobre ecología bentónica y sedimentación de la plataforma continental del Atlántico Sur. UNESCO Seminar, 9-12 May, 1978. UNESCO, Montevideo, p 245-258

Field JG, Clarke KR, Warwick RM (1982) A practical strategy for analysing multispecies distribution patterns. Mar Ecol Prog Ser 8:37-52

Folk R, Ward W (1957) Brazos River Bar: a study in the significance of grain size parameters. J Sedim Petrol 27(1):3-26

Jaramillo E, Fuentealba $S$ (1993) Down-shore zonation of 2 cirolanid isopods during 2 spring-neap tidal cycles in a sandy beach of south central Chile. Rev Chil Hist Nat 66: 439-454

Jaramillo E, McLachlan A, Coetzee P (1993) Intertidal zonation patterns of macroinfauna over a range of exposed sandy beaches in south-central Chile. Mar Ecol Prog Ser 101:105-118

Jaramillo E, McLachlan A, Dugan J (1995) Total sample area and estimates of species richness in exposed sandy beaches. Mar Ecol Prog Ser 119:311-314

Jones D, Hobbins C (1985) The role of biological rhythms in some sand beach cirolanid isopoda. J Exp Mar Biol Ecol 93:47-59

Jones D, Naylor E (1970) The swimming rhythm of the sand beach isopod Eurydice pulchra. J Exp Mar Biol Ecol 4: $188-199$

Legendre L. (1979) Ecologie numerique. Masson, Presses de l'Université du Quebec

McArdle S, McLachlan A (1991) Dynamics of the swash zone and effluent line on sandy beaches. Mar Ecol Prog Ser 76: $91-99$

Editonal responsibility: Otto Kinne (Editor), Oldendorf/Luhe, Germany
McArdle SB, McLachlan A (1992) Sand beach ecology: swash features relevant to the macrofauna. J Coastal Res 8 $398-407$

McLachlan A (1980) The definition of sandy beaches in relation to exposure: a simple rating system. S Afr J Scl 76 $37-38$

McLachlan A, Jaramillo E (1995) Zonation on sandy beaches Oceanogr Mar Biol Annu Rev 33:305-335

McLachlan A, Wooldridge T, Van der Horst G (1979) Tidal movements of the macrofauna on an exposed sandy beach in South Africa. J Zool Lond 188:433-442

Narchi W (1979) Studies on the benthic ecology and functional adaptations of some bivalves correlated with substratum. In: Memorias del seminario sobre ecología bentónica y sedimentación de la plataforma continental del Atlántico Sur. UNESCO Seminar, 9-12 May, 1978 UNESCO, Montevideo, p 185-191

Piñeıro G, Panario D (1993) Dinámica sedimentaria y geomorfológica de dunas y playas de Cabo Polonio. Internal Report, Fac de Ciencias, Universidad de la República Montevideo

Raffaelli D, Karakassis I, Galloway A (1991) Zonation schemes on sandy shores: a multivariate approach. J Exp Mar Biol Ecol 148:241-253

Salvat B (1964) Les conditions hydrodynamiques instertitielles des sédiments meubles intertidaux et la répartition verticale de la faune endogée. C R Acad Sci Paris 259: $1576-1579$

Short S, Wright L (1983) Physical variability of sandy beaches. In: McLachlan A, Erasmus $T$ (eds) Sandy beaches as ecosystems. Junk, The Hague, p 133-144

Weinberg J, Starczak V (1988) Morphological differences and low dispersal between local populations of the tropical beach isopod Excirolana braziliensis. Bull Mar Sci 42 : $296-309$

Zar JH (1974) Biostatistical analysis. Prentice-Hall International, Englewood Cliffs, NJ

Submitted: January 31, 1997; Accepted: October 15, 1997 Proofs received from author(s): December 10,1997 